\title{
Uchodźca i inne nazuy osób opuszczających swój kraj
}

Słowa kluczowe: uchodźca, rzeczowniki osobowe, leksykologia.

doi: http://dx.doi.org/10.31286/JP.101.3.4

Uchodźca był w Polsce słowem roku 2015 ${ }^{1}$. Mimo że minęły już od tego czasu lata, słowo to, niestety, nic nie traci na swojej aktualności. Z tego względu warto się przyjrzeć jego znaczeniu i funkcji w języku polskim na tle innych słów zbliżonych doń znaczeniowo. Jerzy Bartmiński swego czasu tak skomentował wybór tego słowa:

Słowo uchodźca [...] sygnalizuje dramatyczny problem Europy, jakim jest napływ uchodźców (nazywanych też wychodźcami, emigrantami, zbiegami, wygnańcami, tułaczami, uciekinierami z krajów ogarniętych wojną) i zarazem służy testowaniu rzeczywistej gotowości do świadczenia przez Europejczyków międzyludzkiej solidarności (Kwiecień, Łaziński 2019: 64).

W konstelacji słów bliskoznacznych w jakiś sposób z uchodźcą związanych można wymienić znacznie więcej wyrazów. Są to przede wszystkim wyrazy rodzime: cudzoziemiec, obcokrajowiec, wychodźca, wygnaniec, wysiedleniec, zesłaniec, uciekinier, zbieg, wędrowiec, wędrownik, pielgrzym, tułacz, przesiedleniec, osadnik, osiedleniec, przybysz, przychodzień, gość, bezpaństwowiec, przywłoka, przybłęda, włóczykij, włóczęga, łazik, podróżny, podróżnik, obieżyświat, używane rzeczownikowo imiesłowy bierne: wypędzony, wygnany, przesiedlony, zesłany, wykorzeniony, substantywizowane przymiotniki: zamiejscowy, nietutejszy, nieznajomy, obcy, przybyły, przejezdny, przyjezdny, napływowy, a także wyrazy z pochodzenia obce, w tym niektóre będące internacjonalizmami: emigrant, imigrant, migrant, reemigrant, ekspatriant, repatriant, ekspata, kolonista, azylant, banita, apatryda, pionier, alochton, wagabunda, wojażer, globtroter, tramp, nomada, cygan, apatryda, travelbryta, a także urzeczownikowione imiesłowy, jak: deportowany. W niniejszym artykule zostaną omówione w aspekcie semantycznym i pragmatycznym, dotyczącym sposobów używania w tekstach, niektóre z powyższych bliskoznaczników w powiązaniu z tytułowym uchodźca, z położeniem nacisku na te, które odnoszą się do uchodźstwa wywołanego jakimś przymusem, niezgodnego z wolą danej osoby.

\footnotetext{
* renata.przybylska@uj.edu.pl; ORCID oooo-ooo1-7787-6383

1 Wybory słowa roku w latach 2015-2016 były finansowane ze środków programu „Ojczysty - dodaj do ulubionych” Narodowego Centrum Kultury. W 2016 roku „Kapituła profesorów językoznawców w składzie: Jerzy Bartmiński, Jerzy Bralczyk, Andrzej Markowski, Jan Miodek, Walery Pisarek, Renata Przybylska i Halina Zgółkowa wybrała na słowo roku 2015 rzeczownik uchodźca"(http://www.slowanaczasie.uw.edu.pl/slowo-roku-2015-uchodzca, dostęp: 1 września 2020).
} 
Dla nazw wypełniających to pole semantyczne można wskazać następujące znaczeniowo istotne aspekty siatki nominacyjnej nazywanych pojęć i realiów:

(1) To, czy ktoś opuszcza swoje miejsce dobrowolnie czy przeciwnie - pod przymusem. Osoby przymuszone do opuszczenia swego miejsca określane są między innymi słowami: uchodźca, uchodźczyni, wygnaniec, zesłaniec, banita, wypędzeni, wysiedleni, zesłani. Na drugim biegunie sytuują się nazwy osób opuszczających kraj dobrowolnie, takie jak na przykład ekspata.

(2) To, czy opuszczenie miejsca zamieszkania jest tylko czasowe, z zaplanowanym powrotem czy przeciwnie - stałe, $z$ domniemaniem, że jest to działanie nieodwracalne. Czasowe opuszczenie swego miejsca wiąże się z określeniami: podróżny, podróżnik, pielgrzym, wędrowiec, wędrownik, letnik, turysta, wczasowicz, wycieczkowicz. O stałym natomiast informują nazwy: emigrant, imigrant, chyba że otrzymują przydawkę znoszącą tę leksykalną presupozycję, czyli używane są w wyrażeniach takich jak choćby tymczasowy imigrant.

(3) To, jaką rolę osoby migrującej eksponuje jej określenie: czy jest ona subiektem czynności implikującej migrację, na przykład przybysz 'ten, kto przybył', tułacz 'ten, kto się tuła', czy przeciwnie - obiektem czynności wykonywanej przez kogoś innego, jak wygnaniec 'ten, kogo ktoś wygnał', wysiedleniec 'ten, kogo ktoś wysiedlił’

(4) To, z jakiego punktu widzenia postrzegana jest osoba przemieszczająca się - z perspektywy kraju, do którego przybyła, wtedy jest to między innymi imigrant, przybysz, czy kraju, z którego wyjechała: emigrant, wychodźca.

(5) To, jaki jest cel opuszczenia swego miejsca: dobrowolny, związany z pracą: ekspat, ekspata, emigrant ekonomiczny, czy przymusowy, wywołany okolicznościami albo wręcz stanowiący celowo wymierzaną karę: banita, zesłaniec, katorżnik. Osobną grupę tworzą nazwy odnoszące się do ludzi opuszczających swoje miejsce zamieszkania, aby odbyć podróż podejmowaną z powodów rodzinnych, służbowych, religijnych, dla przyjemności, w celach poznawczych bądź turystycznie. Tej grupy nazw nie będę tu analizować, wszystkie bowiem presuponują działanie dobrowolne, połączone z planowanym powrotem do miejsca stałego zamieszkania i życia. Żadne też nie rodzą implikacji, że dana osoba znajduje się w sytuacji życiowo trudnej, a egzystencjalnie często dramatycznej, a wręcz tragicznej.

(6) To, jak postrzegany jest przez innych (zwykle z perspektywy osób, do których przybywa) ten, kto opuszcza swój kraj na stałe - neutralnie (np. przybysz), z niechęcią (np. przybłęda, przywłoka) czy życzliwie (np. gość).

(7) To, czy nazwa nawiązuje do jakiejś czynności, która skutkuje opuszczeniem kraju, a jeśli tak, to jakie czynności są wpisane w jej strukturę słowotwórczą. W wyrazach rodzimych widzimy, że jako ich podstawy wybierane były między innymi czasowniki uchodzić, uciekać, zbiec, przybyć, wygnać, wysiedlić.

Wszystkie nazwy ludzi 'wędrujących' można przeciwstawić nazwom, które odnoszą się do kogoś, kto mieszka gdzieś na stałe i od zawsze, a zatem jest osobą stąd, tutejszym, tubylcem, swoim, naszym, miejscowym, autochtonem, swojakiem, rodakiem, ziomkiem.

Uchodźca jest nazwą osobową z kategorii nazw wykonawców czynności, pochodną słowotwórczo od czasownika uchodzić, utworzoną formantem -ca. SJPDor tak definiuje znaczenie tego słowa: 'ten, kto pod przymusem okoliczności wyjeżdża z miejsca stałego zamieszkania w celu 
stałego lub czasowego osiedlenia się w obcym państwie lub na innym terytorium własnego państwa; emigrant, uciekinier, wychodźca’. Służący za podstawę słowotwórczą czasownik uchodzić zawiera charakterystyczny przedrostek $u$-, tworzący od czasownika chodzić nazwę czynności wykonywanej ukradkiem, odbywającej się stopniowo i niespostrzeżenie. Jak pisze słusznie Aleksandra Janowska (1999: 42) o derywatach od czasowników ruchu z tym przedrostkiem:

W wielu derywatach jednak krystalizowała się nadwyżka semantyczna 'uciekać, działać ukradkiem', co doskonale ilustruje przykład, którym posłużyła się Krupianka 1979: 97: 'od dworu uwolnieni raczej ujeżdżamy, niż wyjeżdżamy’. Definicje podane przy czasownikach z $u$ - wyraźnie uwidaczniają proces leksykalizacji, rozpoczęty prawdopodobnie już w staropolszczyźnie, na przykład: ubiec 'uciec, ujść, umknąć, zbiec, zemknąć', ujechać 'umknąć, uciec jazdą, wyjechać, odjechać ukradkiem', ujść 'idąc, usunąć się [...] uciec, ubiec, zbiec, umknąć.

Czasownik uchodzić w parze z dokonanym ujść konotuje uzupełnienie 'skąd' wyrażone frazą przyimkową z przyimkiem $z$ (czego), na przykład $z$ Afryki, lub 'przed kim/czym', jak w uchodzić przed pościgiem/zemstą. Rodzina słowotwórcza uchodźcy obejmuje takie wyrazy, jak uchodźczyni, uchodźstwo, uchodźczy. Z nich uchodźczyni wygląda na stosunkowo niedawną innowację leksykalną, nie odnotowuje tego słowa ani SJPDor, ani SWJP, ale WSJP PAN ma już takie hasło i datuje jego pierwsze wystąpienie na rok 1924. Przytoczmy cytat z tym słowem z NKJP:

Projekt „Kobiety wędrowne” realizowany jest przez Towarzystwo Interwencji Kryzysowej w związku z inicjatywą: Europejski Rok Równych Szans dla Wszystkich. Do udziału zaproszono kobiety zmuszone do wyjazdu z Polski lub do Polski. To migrantki, uchodźczynie, repatriantki, sybiraczki, osoby przesiedlone i wysiedlone po II wojnie światowej, opuszczające kraj w obawie przed prześladowaniami po 1968 r. i 1981 r., a także w okresie transformacji ustrojowych.

Uchodźca jest obecnie jednym z najczęstszych słów opisujących ludzi, którzy opuszczają na stałe swoje miejsce zamieszkania, swój kraj, swoją ojczyznę. W całym NKJP znajdziemy 11555 jego poświadczeń. Rzeczownik dziedziczy wymagania składniowe swej podstawy, czyli uzupełnianie 'skąd' i 'przed kim/czym', aczkolwiek realizacje z frazą przed kim/czym są rzadkie. Teksty zgromadzone w NKJP ${ }^{2}$ potwierdzają używanie tej nazwy z przymiotnikami wskazującymi na pochodzenie etniczne, religijne lub narodowe uchodźców, najczęściej są to uchodźcy afgańscy/ albańscy/azerscy/arabscy/chorwaccy/czeczeńscy/bośniaccy/greccy/iraccy/kosowscy/kubańscy/ kurdyjscy/libańscy/ormiańscy/palestyńscy/polscy/rwandyjscy/serbscy/sudańscy/tadżyccy/tybetańscy/żydowscy/muzułmańscy itd. Już sama liczba tych określeń wskazuje, jak ogromny zasięg geograficzny ma współcześnie, czyli w szerokim rozumieniu współczesności: w Xx i xxI wieku, zjawisko migracji. Podobną, często dokładniejszą informację o pochodzeniu uchodźców przynoszą kolokacje z wyrażeniem przyimkowym z czego, na przykład uchodźcy z Afrykil Bośni/Haiti/Czeczeni/Konga/Polski/Syrii/Wietnamu/(jakichś) terenów/zachodu/ze wschodu. Zwraca uwagę fraza uchodźcy $z$ Warszawy o referencji historycznej, odnoszona do ludności opuszczającej zrujnowaną przez okupantów niemieckich, spaloną stolicę po klęsce powstania 
w 1944 roku. Uchodźcy sami w sobie stanowią kwestię/problem/sprawę/temat. Obserwuje się ich naplyw. Położenie uchodźców jest postrzegane przez pryzmat ich:

(1) liczby, stąd częste kolokacje: (wielka/jakaś) liczba/rzeka/masy/ttumy/rzeszeltysiącel miliony uchodźców;

(2) formy, w jakich przybywają:fale/kolumny/pochód/strumień/sznur uchodźców;

(3) statusu: nielegalni/cywilni uchodźcy;

(4) samopoczucia: bezdomni/wygłodniali/zmęczeni/zdesperowani/sfrustrowani/przerażeni uchodźcy;

(5) stosunku, jaki mają do nich inni: biedni/nieszczęśni uchodźcy.

Pewne miejsca postrzega się jako zapchane/zatłoczone uchodźcami. Przeciwstawia się tzw. prawdziwych uchodźców uchodźcom określanym mianem ekonomicznych, podkreślając zatem ten aspekt znaczenia słowa, który akcentuje, że uchodźcą nazywamy przede wszystkim kogoś, kto przed czymś uchodzi, czyli ucieka przed jakimś bezpośrednim zagrożeniem. Odpowiednie przydawki kwalifikują i klasyfikują uchodźców, dzieląc ich na: politycznych, religijnych, ekonomicznych, wojennych i eksponując tych prawdziwych. Teksty NKJP poświadczają powstanie nowych kategorii uchodźców. Są to uchodźcy ekologiczni, zmuszeni do opuszczenia swoich miejsc dotychczasowego zamieszkania z powodu katastrof ekologicznych, oraz uchodźcy klimatyczni, przeprowadzający się z powodu zmiany klimatu, która uniemożliwia im mieszkanie i życie w dotychczasowym miejscu. Ta druga kategoria na razie jest kategorią hipotetyczną. Aczkolwiek uchodźcą jest zwykle ten, kto opuszcza granice swojego kraju, to jest jednak kategoria tzw. uchodźców wewnętrznych, którzy migrują z podobnych przyczyn, ale w granicach swojego kraju. W ten sposób w systemie językowym rodzi się opozycja: uchodźcy zewnętrzni i uchodźcy wewnętrzni. Osobliwe kolokacje ukazują niezwykłość losów emigrantów. Wyłania się nawet pojęcie klasycznego uchodźcy:

Każdy z tej szóstki jest klasycznym uchodźcą. Ngo Thi Lan, studentkę z Hanoi, relegowano z uczelni za rozsyłanie e-mailem informacji na temat represji wobec opozycji. - Zatrzymano mnie, byłam śledzona, musiałam uciekać - opowiada (NKJP: W. Duda-Dudkiewicz, Żółty brat patrzy, 2005).

Uchodźcy przybywaja dokądś, koczuja gdzieś, inni przyjmują, przygarniaja uchodźców lub ich nie przyjmuja, wpuszczaja lub nie wpuszczaja, otwieraja przed nimi granice lub przeciwnie - zamykaja granice przed uchodźcami, udzielaja im schronienia lub nie, przemieszczaja ich, rozmieszczaja gdzieś, kierują dokądś, staraja się pomagać, pomóc uchodźcom. Uchodźcy wymagaja pomocy, ale też ochrony.

Ruchy migracyjne sprawiają, że uchodźcy znajdują się ostatecznie w obozach uchodźców, osiedlach uchodźców, ośrodkach dla uchodźców. Na aspekt prawny zwracają uwagę takie kolokacje, jak: prawa uchodźców, status uchodźcy, paszport uchodźcy. Informacje o migrantach docierają dzięki relacjom, zdjęciom uchodźców. W ostatnich latach najczęstszym problemem czy proponowanym rozwiązaniem jest relokacja uchodźców.

Na podstawie czasownikowej zawierającej czasownik chodzić, ale z innym prefiksem, oparty jest wyraz bliskoznaczny wychodźca, zdefiniowany przez sJPDor następująco 'ten, kto opuszcza 
własny kraj, zwykle na zawsze. Widać, że w tej definicji nie mieści się określenie przyczyn opuszczenia własnego kraju. Wychodźca w przeciwieństwie do uchodźcy nie zawiera w swym znaczeniu komponentu wskazującego na to, że dana osoba czegoś się obawia, przed czymś ucieka i dlatego opuszcza swój kraj. Wychodźca to słowo pochodne od czasownika wychodzić w ogólniejszym znaczeniu 'opuszczać dane miejsce'. W całym NKJP ma 250 poświadczeń. Można je uznać za rodzimy neutralny synonim międzynarodowego terminu emigrant. Ze względu na swą historię dla Polaków słowo to ma jednak swoiste konotacje emocjonalne, tym razem związane głównie z emigracją ekonomiczną z Polski drugiej połowy XIX i pierwszej połowy XX wieku. Występowało między innymi w nazwach własnych stowarzyszeń działających na rzecz polskich emigrantów, por. na przykład Towarzystwo Opieki nad Wychodźcami „Opatrzność” w Krakowie. Jest powiązane słowotwórczo z terminem wychodźstwo oznaczającym proces opuszczania swojego kraju albo ogół osób, które go opuściły. Słowo wychodźca współcześnie jest rzadziej używane niż uchodźca. Dane z NKJP wskazują, że najczęściej było i jest odnoszone do emigrantów politycznych i ekonomicznych w XIX wieku i w pierwszej połowie XX wieku.

Wygnaniec to nazwa pochodna od czasownika wygnać, dokładniej oparta na formie imiesłowu biernego wygnany i utworzona sufiksem -ec. Czasownik podstawowy wygnać kogoś skądś znaczy tyle co 'zmusić kogoś do opuszczenia jakiegoś miejsca' i odnosi się do działania ocenianego negatywnie. Rzeczownik wygnaniec dziedziczy tę negatywną aksjologiczną ocenę odniesioną do sprawcy wygnania, nie do osoby - obiektu tej czynności. Najczęstsze współczesne kolokacje z tym rzeczownikiem są następujące: bezdomni/polityczni wygnańcy, przyjaćlprzygarnąć wygnańców, wygnańcy Izraela/Judy. Słowo zostało poświadczone w NKJP 1576 razy. W XIX wieku, w okresie Wielkiej Emigracji, to właśnie ono było chyba najczęściej odnoszone do emigrujących z carskiej Rosji na Zachód Polaków. Zachowało do dziś tę konotację związaną z okresem romantyzmu i męczeństwem narodu polskiego, por.:

Dla Polaka „wygnanie" miało i - jak się zdaje - ma nadal wyraziste konotacje historyczne i kulturowe, w XIX wieku dotyczyło Wielkiej Emigracji, kariery, jaką wtedy zrobiły słowa „wygnaniec”, ,tułacz”, „pielgrzym”. Do takich skojarzeń chętnie, jak wiemy, uciekali się też emigranci po II wojnie, słowo zostało niemal oficjalnie zadekretowane, skoro w Londynie miał swoją siedzibę Rząd Polski na Wygnaniu (NKJP: J. Święch, Nowoczesność. Szkice o literaturze polskiej XX wieku, 2007).

Słowo zostało też utrwalone w śpiewanej do dziś pieśni religijnej: „wygnańcy Ewy, do Ciebie wołamy". Kontekst ten dla chrześcijan zawiera przesłanie, że my wszyscy jako ludzie jesteśmy przecież wygnańcami. Warto też wspomnieć o przydomku Wygnaniec, jaki nadano jednemu z naszych władców, księciu Władysławowi (1105-1159), synowi Bolesława Krzywoustego, który zmarł na wygnaniu w Niemczech, przepędzony z Polski przez swych braci. Nie brak też polskich nazwisk utworzonych do słów wygnaniec, wygnać, wygonić i nawiązujących do tej sytuacji egzystencjalnej, na przykład Wygnalski, Wygnał, Wygnaniec, Wygnanowski, Wygnańczuk, Wygnański, Wygonowski, Wygoński.

Zesłaniec, podobnie jak wygnaniec, pochodzi od formy imiesłowu biernego czasownika zesłać, czyli od zesłany; NKJP poświadcza go 1957 razy. Oznacza osobę odbywającą karę zesłania, 
czyli skazaną na opuszczenie dotychczasowego miejsca zamieszkania i przymusowy pobyt w jakimś zwykle bardzo odległym miejscu. W polskiej świadomości słowo znów kojarzy się przede wszystkim z doświadczeniami ucisku w carskiej Rosji, a następnie represji doświadczanych przez Polaków i nie tylko w Związku Radzieckim. NKJP potwierdza współcześnie używanie słowa przede wszystkim w następujących kontekstach: polscy/syberyjscy zesłańcy, zesłańcy polityczni, zesłańcy do Kazachstanu/na Sybir/na Syberię, zesłańcy Sybiru, zesłańcy i katorżnicy, zesłańcy i łagiernicy. Jak widać, dotyczą one głównie wspomnianych doświadczeń historycznych Polaków w XIX i XX wieku.

Pochodne od czasowników wysiedlić, osiedlić, przesiedlić formacje wysiedleniec, osiedleniec, przesiedleniec to nazwy osoby wysiedlonej (najczęściej przymusowo) z jakiegoś miejsca i przesiedlonej oraz ostatecznie osiedlonej w innym miejscu. Liczne konteksty użyć tych słów odnoszą się do wysiedleń wynikających ze zmian granic w wyniku wojen, ale też do celowych akcji podejmowanych przez władze państw totalitarnych w stosunku do części ludności własnego kraju. W tekstach nazwy te odnoszą się ponadto do osób przesiedlanych w granicach danego państwa, na przykład w związku z koniecznością przeznaczenia zamieszkiwanych przez nie ziem pod budowę zapory wodnej, trasy drogowej, autostrady itp. i wynikającego stąd obowiązkowego wysiedlenia. Dwie z tych nazw to słowa o stosunkowo niskiej częstości użycia wysiedleniec ma w pełnej wersji NKJP 389 poświadczeń, a osiedleniec 295. Cała ta seria nazw jest o tyle interesująca, że dowodzi obecności w siatce nominacyjnej tak istotnego parametru, jak punkt widzenia, z którego dana osoba otrzymuje nazwę. Wysiedleniec to nazwa nadana z punktu widzenia miejsca dotychczasowego zamieszkiwania, czyli z punktu wyjścia, przesiedleniec to nazwa eksponująca zarówno punkt wyjścia, jak i punkt docelowy - miejsce, do którego trafia dana osoba, osiedleniec natomiast kładzie nacisk na spojrzenie na daną osobę z punktu widzenia miejsca, w którym ostatecznie będzie on mieszkał i żył. Bliskoznaczny do osiedleńca jest osadnik - wyraz poświadczony w NKJP 7084 razy, o neutralnym wydźwięku i szerszym znów znaczeniu niż uchodźca: 'osoba, która przybyła na tereny mało zaludnione i tam zamieszkała'. Podobnie sytuuje się synonimiczne słowo kolonista, w jednym ze znaczeń również odnoszące się do osadnika zagospodarowującego teren dotąd słabo zaludniony.

Wypędzony/wypędzeni to określenie w polskim dyskursie publicznym kojarzone głównie z działalnością Związku Wypędzonych, skupiającego Niemców, którzy wskutek wywołanej przez siebie II wojny światowej po klęsce III Rzeszy opuszczali utracone ziemie i osiedlali się w nowych granicach powojennych Niemiec. Określenie to jest tłumaczeniem niemieckiego terminu Vertriebene. W związku z tym wyrazem warto przywołać słowa Stanisława Lema, stanowiące doskonały komentarz historyczny: „Bo ja jestem wypędzony ze Lwowa. [...] Toteż zaczynam każdy wywiad udzielony Niemcom, ich telewizji, radiu, gazetom niemieckim od słów «Ich bin ein Vertriebener»" (Czarnowski 2012: 5). Dobrze też może przytoczyć następującą opinię o tym słowie, skontrastowaną z pojęciem wysiedleńca i wysiedlenia:

Otóż słowo „wypędzeni” nie ma w języku niemieckim takiego dramatycznego znaczenia, jak w polskim. Natomiast wy, Wielkopolanie, używacie określenia wysiedlenie $z$ Kraju Warty, choć w rzeczywistości to właśnie było brutalne wypędzenie (NKJP: M. Nowak, Nasza bliskość jest imponujaca, „Gazeta Poznańska”, 26.02.2005). 
Wspomniane tu wysiedlenie z Kraju Warty jest właściwie niewinnie brzmiącym eufemizmem dla wysiedleń obywateli polskich z Wielkopolski, okupowanej przez III Rzeszę i nazywanej wówczas Wartheland, które stanowiły część wielkiej akcji przesiedleńczej - Generalsiedlungsplan dokonanej przez Niemców w latach 1939-1941.

We współczesnej publicystyce najczęstszym chyba bliskoznacznikiem do słowa uchodźca staje się wyraz uciekinier, formacja z rzadkim przyrostkiem -inier/-ynier utworzona od czasownika uciekać. Znaczenie tego słowa jest oczywiście szersze, oznacza osobę, która ucieka lub uciekła skądś lub przed kimś, bez sprecyzowania obu tych okoliczności. Wydobyte z korpusu NKJP kolokacje potwierdzają jednak, że słowo to jest często odnoszone do uchodźcy, jak w wyrażeniach: uciekinier z Kosowa/Kuby/NRD/Polski/ze Wschodu; uciekinierzy i uchodźcy. W NKJP uciekinier ma 6788 poświadczeń, spośród których warto przytoczyć jeden choćby charakterystyczny cytat: „Samotność uciekiniera, uchodźcy, emigranta to niemalże choroba, z którą można żyć, ale nie można o niej zapomnieć” (A. Zaniewski, Król Tanga, 1979).

Liczne rodzime nazwy osób migrujących pochodzą od czasowników wskazujących na subiekt działania, w tym neutralnych znaczeniowo: wychodźca od wychodzić, przybysz od przybyć, a także nacechowanych ujemnie, implikujących działanie pod przymusem, związane z przykrymi doznaniami: uchodźca od uchodzić, uciekinier od uciekać. Liczniejszy jest zbiór nazw osobowych pochodnych od form imiesłowów biernych czasownika, wskazujących na osobę jako obiekt czyjegoś działania: osiedleniec od osiedlony, osiedlić; wysiedleniec od wysiedlony, wysiedlić; wygnaniec od wygnany, wygnać; wypędzony od wypędzić.

W badanym zbiorze występują dwa złożenia egzocentryczne: cudzoziemiec i obcokrajowiec, nazywające przybysza z punktu widzenia osoby mieszkającej w swoim kraju.

Cudzoziemiec (24 933 poświadczenia w NKJP) to stare polskie słowo, datowane na XIV wiek, o przejrzystej do dziś budowie słowotwórczej: 'ten, kto jest z cudzej ziemi', z rozbudowaną rodziną słowotwórczą: cudzoziemka, cudzoziemski, cudzoziemsko, cudzoziemszczyzna, cudzoziemstwo. Obcokrajowiec (15 875 poświadczeń w NKJP), o podobnej budowie słowotwórczej: 'ten, kto jest z obcego kraju', to słowo o wiele młodsze, bo datowane na pierwszą połowę XIX wieku. Oba wyrazy są synonimami, choć pragmatycznie łączonymi z różnymi kontekstami, co w szczegółach wymaga dokładniejszego przebadania. W obu ujawnia się wielokrotnie analizowana opozycja 'swój - obcy', przy czym interesująca z punktu widzenia rozwoju historycznego jest relacja między bliskoznacznikami przymiotnikowymi cudzy i obcy (Grzegorczykowa 20o8).

Słowo przybysz też mieści się w tym polu znaczeniowym, choć ma szersze znaczenie, bo nie precyzuje, skąd dana osoba przybyła. Może to być przybysz z obcego kraju, ale też ktoś z innej miejscowości albo wręcz tylko przybyły dokądś z miejsca innego niż to, które zajmuje mówiący. Wydobyte z NKJP kolokacje najczęściej wskazują jednak na takie miejsca: przybysz z dalekich stron / z innej planety / z kosmosu / z zagranicy; z Polski / ze Śląska / ze Wschodu / z Zachodu; $z$ Krakowa / $z$ Warszawy; zza oceanu; zza wschodniej granicy, co świadczy o tym, że słowo to odnosi się często do uchodźców.

Wędrowiec według WsJP PAN w pierwszym znaczeniu określa osobę wędrującą pieszo w celach turystycznych, ale już w drugim - kogoś, kto się przemieszcza w celach innych niż turystyczne. W tym drugim może dotyczyć osób opuszczających swój kraj i charakterystyczne 
są dla niego takie kolokacje, jak choćby: spragniony/samotny/zbłąkany wędrowiec. Słowo, notowane po raz pierwszy przez Lindego, jest derywatem od wędrować - adaptacji starego zapożyczenia ze średnio-wysoko-niemieckiego wandern. Pozornie synonimiczny wędrownik nie jest używany w znaczeniu osoby przemieszczającej się w celach innych niż turystyczne ani się nie odnosi do osoby opuszczającej kraj. Można powiedzieć, że wędrownik nacechowany jest pozytywnie, podczas gdy wędrowiec w niektórych użyciach niesie konotacje negatywne. Choć wędrownik jest słowem starszym, to został poświadczony w NKJP tylko 709 razy, podczas gdy wędrowiec - 4453 razy.

Nazwą dla człowieka migrującego i niemającego stałego miejsca zamieszkania jest koczow$n i k$, potwierdzony w NKJP 986 razy. W pierwszym znaczeniu oznacza on człowieka prowadzącego wędrowny tryb życia, przenoszącego się z miejsca na miejsce wraz ze swoim dobytkiem, ale w drugim, przenośnym to ktoś, kto nie ma stałego miejsca zamieszkania, przebywa gdzieś tymczasowo, często w złych warunkach. W tym drugim znaczeniu używa się słowa koczownik na określenie uchodźców. Sytuację egzystencjalną współczesnych koczowników ciekawie komentuje Ryszard Kapuściński:

Wszyscy w jakiś sposób jesteśmy koczownikami i stajemy się nimi coraz bardziej. Dawno temu ludzie wędrowali, by znaleźć żywność i przetrwać. Wraz z wielkimi ruchami migracyjnymi koczownictwo znowu staje się formą życia. Znowu jakbyśmy wracali do naszych początków (Kapuściński 1996: 157).

Synonimem koczownika, ale głównie w jego pierwszym, podstawowym znaczeniu jest słowo nomada (743 poświadczenia w NKJP). Ono również może nabierać nowych sensów, opisujących bliższą nam współczesną rzeczywistość migrantów: „Powstała już wcale liczna warstwa nomadów [...] pracujących pół roku w Niemczech, pół roku na Śląsku” (NKJP: Diabet w kusym fraczku ogonem miesza, „Gazeta Wyborcza”, 28.10.1992).

Sens „przemieszczania się po świecie” mieści się też w słowach wagabunda, włóczykij i włóczęga. Dwa pierwsze mają pozytywną tzw. prozodię semantyczną, ostatnie zaś - negatywną. Wagabunda (528 wystąpień w NKJP) pochodzi z łac. vagabundus i oznacza osobę, która lubi wędrować z miejsca na miejsce, bez ważnego celu. Sytuacja ta jest zatem przez daną osobę pożądana, nie tylko zgodna z jej wolą. To sprawia, że słowo to sytuuje się na peryferiach badanego tu kręgu leksykalnego. Z kolei włóczykij (493 poświadczenia) ma lekki odcień żartobliwy i również oznacza osobę, która lubi się włóczyć, przemieszczać bez ważnego celu, dla przyjemności. Do tych słów dołączyć można kolejny ciąg synonimiczny: powsinoga, obieżyświat, łazik, tramp, globtroter, wojażer. Ponieważ jednak w praktyce nigdy nie odnosi się tych słów do osób opuszczających swój kraj z powodu jakiegoś przymusu, nie będziemy się tu nimi bliżej zajmować. Inaczej rzecz się ma ze słowem włóczęga, które często występuje w kontekście uchodźców i współczesnych migrantów. Jest to słowo bardzo stare, o źródłosłowie prasłowiańskim, ale nadal zachowuje w miarę przejrzystą budowę. Pochodzi od włóczyć się i dziś jest używane, najczęściej z dezaprobatą, w odniesieniu do kogoś, kto nie ma stałego miejsca zamieszkania ani stałego zajęcia. Mówienie z niechęcią o obcym przybyszu związane jest też z takimi słowami, jak przybłęda czy przywłoka. Przybłęda, czyli według sJPDor 'ten, 
co się przybłąkał, błąkając się, zawędrował gdzie; przystał do kogo; przybysz niewiadomego pochodzenia i nieokreślonej pozycji społecznej, włóczęga’, ma 1047 poświadczeń w NKJP. Synonimiczna przywłoka, poświadczona zaledwie 34 razy, wydaje się obciążona silniejszym negatywnym zabarwieniem niż przybłęda.

Silne emocjonalne konotacje znaczeniowe wiążą się dla Polaków ze słowami pielgrzym i tułacz. Na ich szczególny status w pamięci zbiorowej Polaków wpłynął okres Wielkiej Emigracji po powstaniu listopadowym 1830 roku i obraz Polaka jako przymusowego emigranta politycznego w literaturze romantyzmu. Współcześnie pielgrzym w pierwszym dosłownym znaczeniu odnosi się do człowieka odbywającego wędrówkę do miejsca kultu, ma więc konotacje religijne. W użyciach przenośnych, charakterystycznych dla romantyzmu, oznaczał jednak między innymi Polaka, którego tragiczne wydarzenia historyczne, jak rozbiór Polski i panujący pod zaborami ucisk, zmusiły do opuszczenia ojczyzny na zawsze. Adam Mickiewicz w swych Ksieggach narodu polskiego i pielgrzymstwa polskiego, wydanych w 1832 roku w Paryżu, nadał słowu pielgrzym szczególny sens ${ }^{3}$. Pierwotnym jego źródłem jest łac. peregrīnus 'zagraniczny, obcy, cudzoziemiec', w łacinie średniowiecznej brzmiało ono pelegrinus, w polszczyźnie obecne jest od średniowiecza. Jak podaje SJPDor, dawniej słowo to odnosiło się też do człowieka odbywającego podróż, podróżnika, wędrowca.

Tułacz, derywat z sufiksem - acz od czasownika tułać się, ma w SJPDor następującą definicję: 'człowiek, który się tuła, człowiek bez stałego miejsca zamieszkania, nie mający własnego domu, schronienia, dawniej także ten, kto przebywał poza granicami swojego kraju (zwykle wbrew swojej woli), emigrant, wygnaniec'. Ten sam słownik przytacza dwa znamienne cytaty, które ilustrują wspomniane wcześniej znaczenie konotacyjne związane z polskimi emigrantami w XIX wieku: „Być wiecznym tułaczem, nie zobaczyć przed zgonem ojczyzny, którą tak kochałem” (Świętochowski), „Już się do miejsc ani osób, z którymi żyję, nie przywiązuję tak silnie jak w dzieciństwie - i to jest jedną z wad, jaką nabywa serce tułacza” (z listów Słowackiego). Słowo ma 2450 poświadczeń w NKJP i charakterystyczne kolokacje, takie jak wieczny tułacz i bezdomny tułacz.

Podobnie szczególnie nacechowane kontekstem historycznym, odzwierciedlające trudną polską i nie tylko polską historię, zwłaszcza w XIX i XX wieku, i mające zawężone pragmatycznie odniesienie są takie słowa, jak sybirak, sybiraczka, katorżnik, bieżeniec, dipis.

Sybirakami, sybiraczkami nazywa się ludzi wywiezionych lub zesłanych na Syberię w czasach carskiej Rosji lub Związku Radzieckiego. Słowo to miało zatem swe realne odniesienie w bardzo długim okresie zsyłek Polaków, począwszy od rozgromienia konfederacji barskiej w 1768 roku, przez kolejne represje z powodu uczestnictwa w powstaniach, spiskach i antyrosyjskiej konspiracji, na apogeum zesłań na Syberię po upadku powstania styczniowego w 1863 roku skończywszy. W języku potocznym zesłańcy na Syberię byli też nazywani katorżnikami - skazanymi na katorgę. W ściślejszym rozumieniu słowo katorga oznacza zesłanie na ciężkie roboty przymusowe $\mathrm{w}$ ramach kary za jakieś przestępstwo, $\mathrm{w}$ tym polityczne. Osobny rozdział to zesłania Polaków w okresie panowania ZSRR - ich także nazywa się sybirakami. 
O tym, jak ważne i żywe jest to słowo i stojące za nim dramatyczne doświadczenie zsyłki, świadczy liczba poświadczeń we współczesnym przecież korpusie języka polskiego NKJP: 2745 wystąpień, a dla formy żeńskiej (sybiraczka) 89.

Bieżeniec, bieżeńcy to przeniesiona $\mathrm{z}$ rosyjskiego nazwa dla osób, $\mathrm{w}$ tym także Polaków, które w czasie I wojny światowej, między 3 maja a wrześniem 1915 roku, zostały nakłonione przez propagandę władz carskiej Rosji do opuszczenia dotychczasowych miejsc zamieszkania i przeniesienia się w głąb Rosji. Straszono ich mordami, gwałtami i rabunkami, jakich miała się dopuścić armia niemiecka na ludności prawosławnej. Takiej przymusowej ewakuacji poddano wówczas około 3 milionów osób. Na gruncie polskim słowo bieżeniec rozwinęło też nowsze, szersze znaczenie, stając się synonimem każdego uchodźcy czy uciekiniera, por. np. „[...] wśród tłumów bieżeńców, nie spodziewających się sowieckiego ataku, znalazł się we wrześniu 1939 roku we Lwowie" (Czarnowski 2012: 169).

Dipis to z kolei wyraz zapożyczony z języka angielskiego, skrótowiec pochodny od skrótu $D P$ (wymawiane jako „di pi”) utworzonego od ang. displaced person 'osoba przesiedlona'. Oznacza ono obywatela kraju okupowanego przez hitlerowskie Niemcy w czasie II wojny światowej, który został przymusowo wywieziony na roboty do Niemiec, a po zakończeniu wojny nie wrócił do kraju i został w obozie dla przesiedleńców. Według szacunków pod koniec 1945 roku w takich miejscach przebywało około 7 milionów osób.

Hiperonimem dla wszystkich chyba nazw osób opuszczających miejsce stałego zamieszkania na długo i z zamiarem osiedlenia się gdzie indziej jest współcześnie słowo migrant, mające 882 poświadczenia w NKJP. Bezpośrednie hiponimy leksykalne oparte na tym samym rdzeniu to emigrant (9795 użyć w NKJP) i imigrant (7608 użyć). Emigrant, notowany najwcześniej przez swil, jest słowem międzynarodowym, czyli internacjonalizmem, i pochodzi od łac. emigrans 'opuszczający swoje miejsce zamieszkania, przenoszący się w inne miejsce'; imigrant jest późniejszy, notuje go dopiero sJPDor, i pochodzi od łac. immigrans; natomiast migrant jest jeszcze młodszy, w SJPDor mamy cytat z $1967 \mathrm{r}$. W tej rodzinie wyrazów mamy jeszcze reemigranta (207 poświadczeń w NKJP) oznaczającego osobę powracającą do ojczyzny z emigracji, wyraz odnotowany w SJPDor z ilustrującym go cytatem z 1953 roku, z łac. 're = na nowo + emigrant'. $\mathrm{Z}$ tymi nazwami połączony jest formalnie czasownik migrować 'zmieniać miejsce stałego zamieszkania, przesiedlać się.

Do nazw mających także źródłosłów łaciński, oparty na łac. patria ‘ojczyzna’ należą nazwy repatriant (2 979 użyć) i ekspatriant (zaledwie 12 poświadczeń). W pierwszym z nich mamy prefiks re-, z łac. 're- = na nowo'. Słowo zdefiniowane jest w SJPDor następująco: 'obywatel jakiegoś kraju powracający do ojczyzny po dłuższym pobycie na obczý́nie, zwykle o powracających do kraju przesiedleńcach, wychodźcach, jeńcach wojennych' i opisane jako pochodne od łac. repatrians 'powracający do kraju. Warto zaznaczyć, że słowem repatriant w warunkach powojennej Polski określano głównie Polaków z Kresów Wschodnich, którzy po zmianie granic dokonanej przez zwycięskie mocarstwa po II wojnie światowej opuszczali swoje rodzinne strony, wcielone do Związku Radzieckiego, żeby się osiedlić w granicach powojennej Polski. Najczęściej trafiali na tzw. Ziemie Zachodnie lub Ziemie Odzyskane, jak nazywała je propaganda polityczna PRL. O nich nie można powiedzieć, że powracali do ojczyzny, bo 
nigdy jej nie opuścili ${ }^{4}$, a zatem mamy tu do czynienia z pewnym semantycznym nadużyciem. W związku z tym niektórzy postulowali wprowadzenie do słownika trafniejszych terminów: (1) depatriant - z funkcjonującym jako pierwszy człon złożenia łac. prefiksem de-, sygnalizującym zaprzeczenie, pozbawienie lub odwrotność tego, co oznacza drugi człon, lub (2) ekspatriant z funkcjonującym jako pierwszy człon złożenia łac. prefiksem eks-, oznaczającym wyłączanie, wykluczanie z czegoś. Słowo ekspatriant, odnotowane w korpusie NKJP, ale nieobecne ani w SJPDor, ani w innych słownikach, oznacza - zgodnie z etymologią - osobę pozbawioną ojczyzny, mieszkającą poza ojczyzną. Nie ma jednak wydźwięku negatywnego, pod względem emocjonalnym jest neutralne. Cytaty świadczą o tym, że odnosi się po prostu do osoby mieszkającej z różnych powodów poza swoim krajem ojczystym, na przykład:

Wyspy Karaibskie? Brzmi kusząco. Ale za Boga nie znajdziesz tam roboty. A to oznacza, że dzień w dzień będziesz kończył jak wszyscy inni ekspatrianci - z klimfą czerwoną z przepicia jak burak, zastanawiając się, czy nikt nie zobaczy, jak o godzinie 10 strzelasz sobie małą, stawiającą na nogi lufkę (NKJP: J. Clarkson, Rozważ emigrację!, „Dziennik Zachodni”, 14.11.2009).

W relacji hiponimii do imigranta i imigrantki pozostają słowa azylant (590 poświadczeń) i azylantka, nazywające osoby, którym dane państwo udzieliło azylu (schronienia) w sytuacji prześladowania grożącego im we własnym kraju z powodów politycznych, rasowych itp. Charakterystyczne dla tego słowa kolokacje to między innymi: azylant polityczny; azylanci i cudzoziemcy/imigranci/uchodźcy; dom/ośrodek/schronisko dla azylantów; atak na azylantów.

Wśród jednostek obcego pochodzenia zwraca uwagę słowo bardzo rzadkie, z warstwy słownictwa erudycyjnego, apatryda (zaledwie 31 użyć w NKJP), oznaczające osobę bez przynależności państwowej, pochodzące od grec. apatris 'pozbawiony ojczyzny'. Jego rodzimym synonimem jest bezpaństwowiec - poświadczony w NKJP 352 razy.

Równie rzadka nazwa osoby opuszczającej swój kraj to egzul - poświadcza go zaledwie 8 użyć w NKJP, wszystkie z powieści Władysława Reymonta Rok 1794, co pozwala zakwalifikować słowo jako przestarzałe. W źródłach leksykograficznych pojawia się w kilku wariantach: egzul, egzulant albo eksulant, między innymi w internetowym słowniku polsko-angielskim ${ }^{5}$, ale co ciekawe, jest notowane przez SJPDor z kwalifikatorem „dawne”, zilustrowane cytatami typu: „Eksulanci, czyli szlachta wypędzona z trzech powiatów ukraińskich, dopraszała się natarczywie, aby dano jej odszkodowanie” i objaśnione jako pochodne od łac. exulant, exulantis 'wygnany'.

Banita to wyraz wywodzący się z łaciny, poświadczony w NKJP 703 razy, oznaczający osobę skazaną na banicję (łac. bannitio), czyli wygnanie z kraju stanowiące karę za wykroczenie przeciw obowiązującemu prawu. Kara taka była stosowana już w starożytności i wiązała się nie tylko z wygnaniem, ale także utratą czci. Banita był osobą wyjętą spod prawa, kimś, kogo można było bezkarnie zabić. Współcześnie prawo międzynarodowe nie dopuszcza takiej

4 Analiza pojęć repatriacja i depatriacja zob. Artur Czesak, http://poradnia.pwn.pl/lista.php? szukaj=depatriacja\&kat=18 (dostęp: 1 września 2020). 5 educalingo.com/pl/dic-pl/eksulant (dostęp: 1 września 2020). 
kary, w odniesieniu do obecnych realiów używa się więc tego słowa w ogólniejszym znaczeniu osoby, która z powodu jakiegoś przymusu, najczęściej politycznego, opuściła kraj. W kulturze popularnej najsłynniejszą postacią banity jest Robin Hood, bohater średniowiecznych angielskich legend ludowych, przywódca grupy podobnych sobie ludzi wyjętych spod prawa, czyli właśnie banitów. W historii Polski najbardziej osławionym banitą był z kolei Samuel Zborowski (1540?-1584) skazany na wygnanie przez króla Stefana Batorego.

Współcześnie obserwujemy dalsze rozszerzanie znaczenia tego słowa, widoczne między innymi w takich użyciach: artystyczny/finansowy/sportowy banita, które prowadzi do nowszego sensu 'osoba wykluczona z jakiegoś środowiska, z jakiejś grupy', np.:

Sławińska i Zgorzelski przybyli jako banici z Torunia, gdzie władze komunistyczne pozbawiły ich praw nauczania. Szybko jednak zadomowili się w Lublinie i otworzyli swe skromne domy również dla studentów, z którymi związała ich przyjaźń trwająca dłużej niż lata studiów (NKJP: A.M. Wierzbicki, ...na ziemi w Lublinie..., 2008).

Stosunkowo często, co poświadcza NKJP, używa się tego określenia w stosunku do zawodników na jakiś czas odsuniętych od gry w zespole, np.:

Obrońca Olympiakosu Pireus jest zadowolony, że cieszy się dużym zaufaniem trenera Leo Beenhakkera. Nie znaczy to jednak, że zapomina o zawieszonych kolegach. - Mam nadzieję, że ich brak nie zaważy na wynikach eliminacji. Liczę, że banici wrócą do kadry szybciej, niż myślicie (NKJP: R. Patroniak, Wspomnienia ze Lwowa powracaja we Wronkach, „Dziennik Zachodni", 02.09.2008).

Osobnego komentarza wymagają dwa słowa w tym polu leksykalno-semantycznym chyba najnowsze. Pierwsze z nich to ekspata, zapożyczenie z angielskiego oznaczające wysokiej klasy specjalistę, który dobrowolnie opuścił swój kraj, aby pracować za granicą. Słowo znane jest też w wariancie morfologicznym ekspat, a kim są osoby określane nim w Polsce, można wywnioskować z poniższych cytatów:

Mniejsza emigracja odlatuje z warszawskiego Okęcia samolotem rejsowym. Tam, dokąd zmierza, tanie linie nie docierają. Kierunek: Rosja, Ukraina, inne kraje bloku wschodniego. Ta druga grupa jest dyskretna. Kibicują jej rodziny i przyjaciele. Jedzie tam pokolenie 30-40-latków. Wykształceni, doświadczeni, światowi. Nie myślą o sobie jak o emigrantach. Wolą być nazywani ekspatami ( $\mathrm{z}$ ang. expatriot - poza ojczyzną). Cenieni nad Wisłą, zajmowali tu wysokie lub średnie stanowiska. Niejedna firma usiłowała ich skusić. Na przeprowadzkę na Wschód namówili ich łowcy głów, którzy przeczesują rynek pracy w poszukiwaniu najlepszych. Zatrudniani na kontraktach przez wielkie koncerny w Moskwie, Petersburgu, Nowosybirsku, traktują to jak wyzwanie, szansę na dużą karierę i wielkie pieniądze. Szacuje się, że ta mała emigracja na Wschód to już kilkanaście tysięcy osób (NKJP: P. Stasiak, Kierunek Moskwa, „Polityka”, 29.07.2006).

Rodzice to w trzech czwartych ekspaci (pracujący w polskich przedstawicielstwach swoich firm obcokrajowcy), w jednej czwartej - „świadomi, inteligentni, sympatyczni i zamożni” Polacy, 
wedle określenia dyrektor Małgorzaty Tarnowskiej. - Świadczymy usługi pedagogiczne na bardzo wysokim poziomie - tłumaczy fenomen przedszkola (NKJP: A. Niezgoda, Dzieci skazane na sukces, „Polityka”, 20.09.2003).

Istnieje już żeńska formacja pochodna od tego rzeczownika: ekspatka, por. „Lucy Vanel to amerykańska ekspatka z północnej części stanu Nowy Jork, która od piętnastu lat mieszka w Lyonie" (DeSanctis 2016: 221).

Drugie świeże słowo w tym polu semantycznym, na razie mające status okazjonalizmu, to neologizm słowotwórczy travelbryta, kontaminacja dwóch wyrazów: celebryta i ang. travel 'podróż. Definiuje się go następująco:

Słowem travelbryta Cywiński opisuje każdego, kto kreuje opowieść o sobie w oparciu o podróże, i nie chodzi o zwykłe podróże z plecakiem do egzotycznych krajów, lecz o wyjazd w nieznane z celebrytą, a właściwie travelbrytą, czyli podróżnikiem zarabiającym na znanej twarzy (Płociński 2016: 17-18).

Sytuacja, w której człowiek z różnych powodów i w różnych okolicznościach opuszcza swoich bliskich, swoje miejsce, w którym się urodził i dotychczas żył, udaje się w nieznane i tam zaczyna nowe życie, przez wieki była zapewne udziałem wielu ludzi, co odbiło się nie tylko w zbiorze częściowo tu opisanych rzeczowników pospolitych, ale też choćby w polskich nazwiskach. Najpopularniejsze z nich nazwisko Nowak - 187732 nosicieli (ISNP) - oddaje przecież nie co innego, tylko określenie człowieka z punktu widzenia pewnej grupy postrzeganego jako 'nowy', czyli skądś przybywający, nietutejszy. Pokrewne nazwiska także popularne w Polsce to: Nowakowski, Nowacki, Nowicki, Nowaczek, Nowaczyński itd. Do częstych polskich nazwisk odzwierciedlających postrzeganie ludzi „nie stąd”, należą też te pochodne od podstawy czasownikowej przybyć (dokądś), przychodzić (skądś, dokądś), oznaczające tego, kto przybył, przyszedł, i mające na przykład postać: Przybycień, Przybylak, Przybysz, Przybyła, Przybyłko, Przybyłowicz, Przybyłowski, Przybylak, Przybylik, Przybylinski, Przybylski, Przybyszewski, Przybądź, Przybędzki, Przychodzki, Przychodzień, Przychodniak, Przychodny.

Z grupą leksykalną nazw osób opuszczających swój kraj ściśle związane są nazwy działań i czynności skutkujących taką sytuacją. Mieszczą się tu nazwy o źródłosłowach rodzimych, słowotwórczo spokrewnione z omówionymi wyżej nazwami osobowymi: uchodźstwo, wychodźstwo, wysiedlenie, przesiedlenie, osiedlenie, wypędzenie, wygnanie, zesłanie, a także te z pochodzenia obce: migracja, emigracja, imigracja, ekspatriacja, bieżeństwo. Do tego zbioru trzeba dodać nazwy niespokrewnione z nazwami osobowymi: zsyłka, wywózka, wydalenie, deportacja. Zsyłka (1203 poświadczenia w NKJP) jest wyrazem zazwyczaj odnoszonym do kar zesłania zasądzanych w carskiej i komunistycznej Rosji. Wywózka (2281 poświadczeń w NKJP) z kolei występuje w kontekstach odnoszących się do II wojny światowej - wywożenia Polaków przez władze sowieckie na Daleki Wschód (najczęściej do Kazachstanu), a przez okupanta hitlerowskiego na roboty do Niemiec.

Bogactwo słów w języku polskim odnoszących się do osób opuszczających swój kraj na stałe świadczy o istotności tego doświadczenia w pamięci zbiorowej Polaków. Język polski reagował i reaguje na wydarzenia historyczne wymuszające migrację, włączając do swojego 
słownika nazwy odzwierciedlające kolejne traumatyczne losy migrantów. Co do pochodzenia są to zarówno liczne słowa oparte na źródłosłowach rodzimych, jak i zapożyczenia, z których część ma status internacjonalizmów. Użycie tych nazw często jest ściśle związane z określonym kontekstem historycznym. Pewne nazwy niosą ze sobą silne konotacje emocjonalne. Całość zbioru nazw zawierających sens 'opuszczający swój kraj' stanowi ważny składnik tzw. mapy mentalnej Polaków.

Bibliografia

Grzegorczykowa R. 2008: Od wspólnoty do obcości. Rozwój znaczeniowy polskiego przymiotnika obcy na tle słowiańskim, „Etnolingwistyka”, z. 20, s. 39-50.

Czarnowski R.J. 2012: Lwów. Sacrum et profanum, Galaktyka, Łódź.

DeSanctis M. 2016: 100 miejsc we Francji, które każda kobieta powinna odwiedzić, Wydawnictwo Literackie, Kraków. ISNP: Internetowy słownik nazwisk w Polsce: nazwiska.ijp.pan.pl (dostęp: 1 września 2020).

Janowska A. 1999: Funkcje przestrzenne przedrostków czasownikowych w polszczyźnie, Wydawnictwo Uniwersytetu Śląskiego, Katowice.

Kapuściński R. 1996: Lapidarium II, Czytelnik, Warszawa.

Krupianka A. 1979: Czasowniki z przedrostkami przestrzennymi w polszczyźnie XVIII wieku, Państwowe Wydawnictwo Naukowe, Warszawa-Poznań-Toruń.

Kwiecień M., Łaziński M. (red.) 2019: Słowa roku, słowa miesiąca, słowa dnia, Wydział Polonistyki Uniwersytetu Warszawskiego, Warszawa.

L: S.B. Linde, Słownik języka polskiego, t. 1-6, Drukarnia Zakładu Ossolińskich, Lwów 1854-1860.

NKJP: Narodowy Korpus Języka Polskiego (online: nkjp.pl).

Płociński M. 2016: Wakacje z celebrytą, „Rzeczpospolita. Plus Minus” nr 294, s. 17-18.

SJPDor: Słownik języka polskiego, red. W. Doroszewski, t. 1-11, Państwowe Wydawnictwo Naukowe, Warszawa $1958-1969$. swil: Słownik języka polskiego, t. 1-2, wyd. staraniem i kosztem M. Orgelbranda, Wilno 1861 (Słownik wileński).

SWJP: Słownik współczesnego języka polskiego, red. B. Dunaj, Wilga, Warszawa 1996.

WSJP PAN: Wielki słownik języka polskiego PAN, red. P. Żmigrodzki (online: http://www.wsjp.pl/).

Summary

\section{Uchodźca ('refugee') and other names of people leaving their country}

Keywords: uchodźca ('refugee'), personal nouns, lexicology, mental map.

The article is devoted to the semantic-pragmatic analysis of the word uchodźca ('refugee'), chosen for the word of the year 2015, and discussing other synonymous names of people leaving their country. The author cites lexicographic data, mainly from Słownik języka polskiego edited by Witold Doroszewski and Wielki słownik jezzyka polskiego PAN as well as information about the frequency and typical contexts of the words under discussion, extracted from the National Corpus of Polish. It shows the mutual connections between lexemes in this semantic field and the place of these words on the mental map of Poles. 